Received: 06.10.2011

Corrected: 19.1.2012.

Accepted: 24.1.2012

Available online: 15.2.2012.

\title{
Seismic Behaviour and Retrofit of Historic Masonry Minaret
}

\section{Authors:}

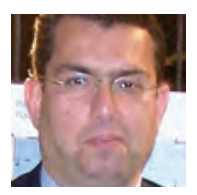

Prof. Ahmet Murat Turk, Ph.D. (Civ.Eng.)

Istanbul Kultur University

Civil Engineering Department

murat.turk@iku.edu.tr

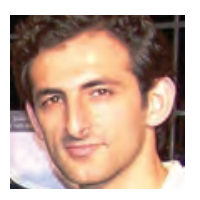

Cumhur Cosgun, B.Sc. (Civ.Eng.)

Istanbul Kultur University

Civil Engineering Department

c.cosgun@iku.edu.tr
Ahmet Murat Turk, Cumhur Cosgun

Professional paper

\section{Seismic Behaviour and Retrofit of Historic Masonry Minaret}

The dynamic behaviour of block masonry minaret of a historical mosque in Istanbul is analyzed, and a seismic retrofit method is proposed. Due to high seismicity of the region, a $3 \mathrm{D}$ finite element model is used to determine lateral displacements and failure modes under seismic load. The analyses show that the highest damage usually occurs at the base and the lower part of the minaret, and that lateral behaviour can be improved by strengthening these sections with fiber reinforced polymer (FRP) sheets. The results obtained are promising in terms of seismic protection.

Key words:

historic masonry structure, minaret, retrofit, earthquake, fibre reinforced polymer (FRP)

Stručni rad

Ahmet Murat Turk, Cumhur Cosgun

\section{Seizmičko ponašanje i sanacija povijesnog zidanog minareta}

U radu se razmatra dinamičko ponašanje blokovima zidanog minareta povijesne džamije u Istanbulu i metoda protupotresne sanacije. S obzirom na visoku seizmičku aktivnost regije, za određivanje bočnih pomaka i načina otkazivanja uslijed seizmičkih djelovanja odabran je prostorni model konačnih elemenata. Provedene analize pokazuju da se najveća oštećenja obično pojavljuju u podnožju i donjem dijelu minareta, te da se ojačavanjem tih dijelova trakama od polimera armiranog vlaknima (engl. FRP - Fiber Reinforced Polymer) poboljšava otpornost na bočne sile. Postignuti rezultati su u smislu seizmičke zaštite obećavajući.

Ključne riječi:

povijesna zidana gradevina, minaret, sanacija, potres, polimer armiran vlaknima (FRP)

Facbericht

Ahmet Murat Turk, Cumhur Cosgun

\section{Seismisches Verhalten und Sanierung des historischen gemauerten Minaretts}

In der Arbeit wird das dynamische Verhalten der Blöcke des gemauerten Minaretts der historischen Moschee in Istanbul sowie die Methode der erdbebensicheren Sanierung erörtert. Hinsichtlich der hohen seismischen Aktivität dieser Region, wurde zum Zwecke der Feststellung von Setzungen und der Art und Weise des Einsackens des Gebäudes infolge von seismischen Wirkungen das Raummodell der Finite-Elemente-Methode ausgewählt. Die Analyseresultate zeigen, dass die größten Beschädigungen üblicherweise am Fuße sowie am unteren Teil des Minaretts erscheinen und mit der Verstärkung dieser Teile durch Streifen aus Faser- Kunststoff-Verbund (FKV) der Widerstand gegen die Seitenkräfte verbessert wird. Die Resultate sind im Sinne des seismischen Schutzes vielversprechend. 


\section{Introduction}

Earthquakes rank among the most important natural threats in Turkey and in other earthquake-prone regions worldwide. As Turkey is located in one of the most seismically active regions of the world, it is quite understandable that a considerable attention is given to the problem of seismic protection of historical heritage. Structural engineers always find the analysis and design of such structures quite challenging, especially because of highly complex behaviour of materials these structures are formed of. The problem becomes even more complex when dynamic behaviour is included in the analysis. The earthquakes that occurred in the northwest of Turkey on 17 August 1999 (Kocaeli EQ, $M_{w}=7,5$ ) and 12 November 1999 (Düzce EQ, $M_{w}=7,2$ ) caused considerable casualties, damage and structural failure of various buildings, including many minarets and mosques. Much older historical structures also experienced different levels of damage during major earthquakes that occurred in a more distant past.

Some significant events from Ottoman Era are earthquakes that occurred in 1556 and 1894. In fact, after the 1894 Istanbul earthquake, 69 minarets in the city were reported damaged, and 30 of them actually collapsed.
Thanks to advancements made in the dynamic testing of structures, and in development of computational methods in structural analysis, significant results have been achieved in the study of mechanical behaviour of historic structures [1, 2, $3,4,5,6,7,8]$. These studies are crucial not only from the point of view of protection, but also for analysis of ground motion that occurred during past earthquakes. Within this framework, dynamic properties of old masonry minarets, which usually exhibit vulnerable behaviour under seismic load, are investigated.

Two minarets of Dolmabahce Mosque in Istanbul are presented in Figure 1. The one situated at the west side of the mosque is actually considered in the paper. The Dolmabahce Mosque, built during Ottoman Empire in 1855 near the Dolmabahce Palace, is characterized by neo-classical and baroque architectural style. The mosque is located to the south of Dolmabahce Palace, on the European side of the Bosphorus Strait. Two minarets rising from the eastern and western sides of the mosque exhibit a strong mixture of baroque and rococo styles. Although both minarets are practically identical, the west-side minaret has preserved its original form, while the other one was recently restored. This study mainly focuses on the west-side minaret, so that the
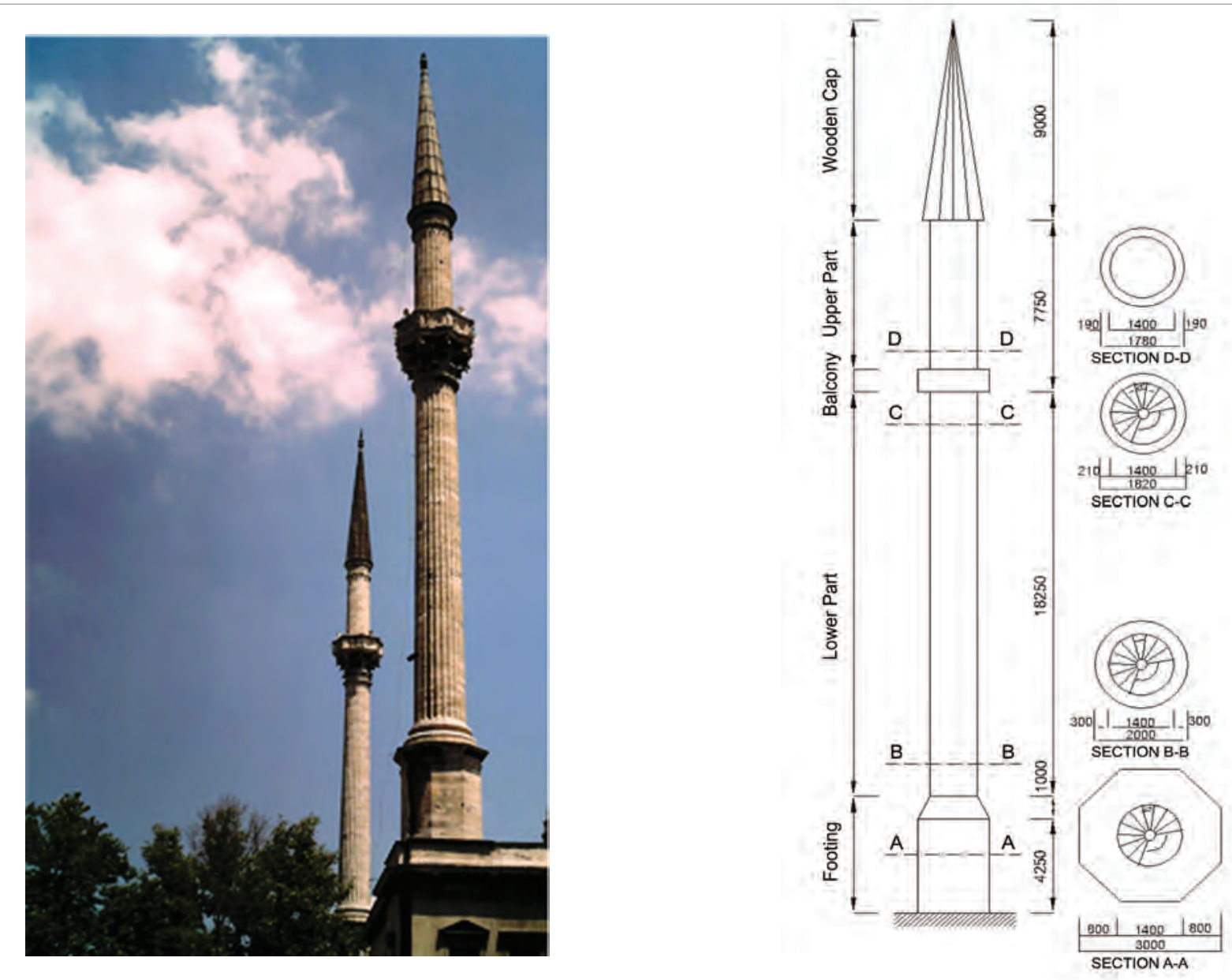

Figure 1. View of Dolmabahce Mosque minarets with their main features (dimensions in mm) 
real mechanical behaviour of the structural system (Figure 1) can be determined.

The minaret footing is made of very thick stone blocks, and is connected with the exterior wall of the mosque. It can be identified as a slender cantilever structure. The lower part, from bottom to the gallery, is formed of the wall envelope, stairs and the core. In this segment, the thickness of the masonry wall decreases along the height. The interior of the upper part, from gallery to the top of minaret, is empty and has no practical use. Here, the wall thickness is constant along the entire height. Balconies are mostly used for prayers, which creates a mass concentration along the minaret's height, and affects its dynamic structural response [1]. This part is narrower when compared to the bottom part of the minaret. The conical top of the minaret is made of zinc-coated timber (Figure 1).

The understanding of dynamic behaviour of masonry minarets is of great significance for proper preservation and strengthening/ retrofitting of historical monumental structures. During a case study conducted earlier on the same minarets by a research team from the Istanbul Technical University, micro tremor measurements were conducted, and a finite element model of the minaret based on shell elements was prepared using the SAP2000 software. In its conclusion, the study provides model analysis results and proposes mechanical properties of the structural system [1]. Sezen et al. discuss vulnerability of and damage to 64 masonry and reinforced-concrete minarets after the 1999 Kocaeli and Duzce earthquakes, and investigate seismic response of reinforced-concrete minarets [7]. In 2008, Dogangun et al. analyzed and evaluated behaviour of unreinforced masonry minarets subjected to dynamic earthquake load [8].

In this study, the dynamic behaviour of a representative minaret made of natural block stone is investigated using a finite element software [9]. The structure is modelled and examined using the response spectrum analysis described in the TSC - Turkish Seismic Code [10].

\section{Description of minaret structure}

As shown in Figure 1, the $40.25 \mathrm{~m}$ high minaret is formed of the following segments: base ( $4.25 \mathrm{~m})$, transition segment ( $1 \mathrm{~m})$ cylindrical body $(26 \mathrm{~m})$, and wooden cap $(9 \mathrm{~m})$. The outer diameter and thickness of the cylinder differ in each part of the minaret. The minaret wall thickness is $30 \mathrm{~cm}$ at the lower part, and this thickness gradually comes down to $21 \mathrm{~cm}$ at the upper part of the minaret, i.e. the thickness reduces by $1 \mathrm{~cm}$ for each $2 \mathrm{~m}$ of the height. At the base, the outer diameter and thickness of the wall are $3 \mathrm{~m}$ and $0.8 \mathrm{~m}$, respectively, while in the lower part they are $2 \mathrm{~m}$ and $0.3 \mathrm{~m}$, in the balcony part $1.8 \mathrm{~m}$ and $0.2 \mathrm{~m}$ and, finally, in the upper part $1.78 \mathrm{~m}$ and $0.19 \mathrm{~m}$, respectively [1].

During construction of the minaret, the limestone (also known as kufeki stone or maktarali limestone) was used for all the structures forming the Dolmabahce Mosque. Later on, during renovation of the mosque, numerous material tests were performed on limestone specimens taken from residues of old historical structures and ancient quarries near Istanbul. The final report on limestone samples was published in 2000 by Istanbul Technical University. Typical mechanical properties of kufeki stone are given in Table 1 [1]. Interestingly, kufeki stone was also used by Mimar

Table 1. Mechanical properties of kufeki limestone [1]

\begin{tabular}{|l|c|c|c|}
\hline Physical Properties & Max. & Min. & Average \\
\hline Density (dry, kN/m³) & 25,0 & 22,8 & 23,9 \\
\hline Density (fully saturated, kN/m³) & 25,3 & 23,7 & 24,5 \\
\hline Uniaxial Compressive Strength (MPa) & 19,2 & 12,3 & 16,7 \\
\hline Uniaxial Tensile Strength (MPa) & 0,95 & 0,88 & 0,9 \\
\hline Modulus of Elasticity (GPa) & 7,36 & 4,30 & 5,84 \\
\hline
\end{tabular}

Sinan, the most famous architect of the Ottoman Empire who lived between 1489 and 1588, for construction of almost all historical structures around Istanbul. This stone belongs to Miocene formations and has a high CaCO3 content (93-100\%). It's a natural composite material with the matrix structure formed of accumulated and metamorphosed sea shells.

Mechanical properties of kufeki limestone are: modulus of elasticity of uncracked stone section $\mathrm{E}=8856 \mathrm{MPa}$, Poisson ratio $v=0,24$, and unit weight $\gamma=23 \mathrm{kN} / \mathrm{m}^{3}$. While calculating the elastic modulus of the limestone material $(\mathrm{E}=8856 \mathrm{MPa})$ it was assumed that the elastic modulus to compressive strength ratio is $\mathrm{E} / \mathrm{f}_{\mathrm{c}}=720$, where $\mathrm{f}_{\mathrm{c}}=12,3 \mathrm{MPa}$ (minimum compressive strength of kufeki stone) is the value taken from Table 1. The ratio of modulus of elasticity to the compressive strength of material, 720 , is taken from a previous experimental study in which mechanical properties of kufeki limestone were extensively tested. According to this study, the typical uniaxial compressive strength to uniaxial tensile strength ratio ranges from 11 to $12[11,12,13,14]$.

\section{Dynamic analysis of structure and evaluation of results}

The 3D finite element model, developed to study dynamic behaviour of the minaret, is shown in Figure 2. The model includes spiral stone-made stairs, which are fixed to external minaret walls. The dead load of the wooden cap (upper part of minaret) is uniformly distributed along the top of minaret wall.

As to boundary conditions, the base of the minaret is considered as a xed support. As can be seen in Figure 1, the base part of the minaret is connected with the thick external wall of the mosque, which is why no soil-structure interaction, nor rotation of minaret base, were taken into account.

The linear elastic material behaviour is assumed in the structural model, while the changes in stiffness are neglected. It is assumed that minaret is located in a highly seismic region with weak soil 


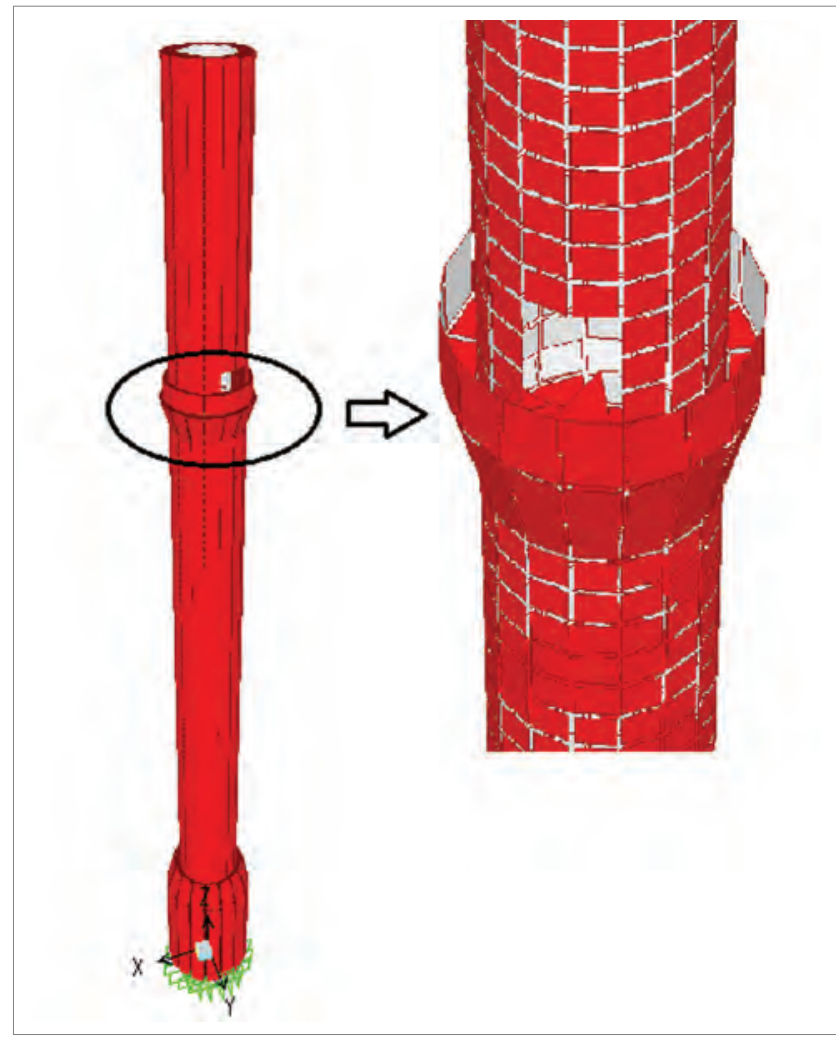

Figure 2. 3D minaret model with the close-up view of the balcony

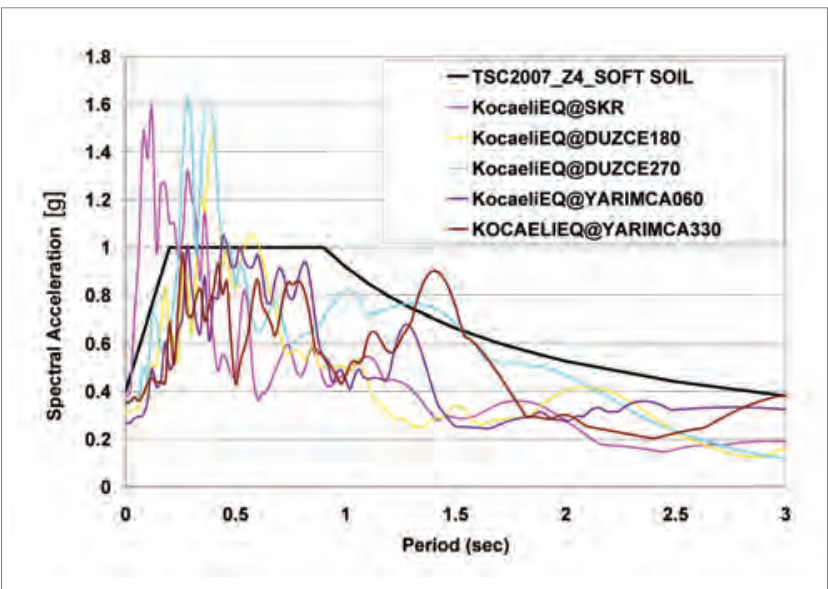

Figure 3. Comparison between the design response spectrum and spectra from previously recorded earthquakes

layers, i.e. in the $1^{\text {st }}$ seismic zone and soil class Z4 according to TSC 2007 [10]. The Type D soil class is assumed according to Eurocode 8 [15]. In order to simulate possible elastoplastic behaviour of the minaret, it is assumed that the seismic load reduction factor (factor $\mathrm{R}$ ) for masonry minarets amounts to 2 according to [10], while the behaviour factor q (similar to factor R) for masonry tower walls according to Eurocode 8, Part 6 , Annex E [16] amounts to 1,5 . The $2 \%$ damping ratio is assumed for the dynamical analysis of such structures. The second order effect (P-delta) is ignored in the analysis. Dynamic analysis of the minaret model is carried out using the response spectrum defined in [10]. The design response spectrum determined for Z4 type soil, with $2 \%$ damping for the highest seismic activity in Turkey, is presented in Figure 3. This figure also shows spectral properties of previous major earthquakes recorded in 1999 in soft soil conditions. As can be seen, the design response spectrum determined according to [10] is comparable with spectra based on recorded accelerations.

The first five modal periods of the minaret model (determined through modal analysis), and contribution of individual modes to dynamic response, are presented in Table 2 . The fundamental period of the minaret obtained through modal analysis is very similar to that obtained through ambient vibration measurements. The first four modes greatly contribute to the overall response, with the first one participating with as many as $34 \%$ in the total response. The torsional mode ( $5^{\text {th }}$ mode) has practically no effect on the response of the minaret. Micro tremors caused by ambiental vibrations were measured on the minaret structure,

Table 2. First five modes and their participation factors

\begin{tabular}{|l|c|c|c|c|c|}
\hline Modes & 1. & 2. & 3. & 4. & 5. \\
\hline Direction & Lateral & Lateral & Lateral & Lateral & Lateral \\
\hline Period [s] & 1,21 & 1,21 & 0,20 & 0,20 & 0,08 \\
\hline $\begin{array}{l}\text { Modal participation } \\
\text { factor (\%) }\end{array}$ & 34,0 & 34,0 & 13,0 & 13,0 & 1,0 \\
\hline
\end{tabular}

and the fundamental frequency of $0,88 \mathrm{~Hz}$ and the period of 1,136 sec were obtained [1]. In this study the first period amounted to 1,21 s (Table 2). The $6 \%$ difference can be assumed as negligible for practical design purposes.

Lateral displacements at the top of the minaret, calculated during the response spectrum analysis, are shown in Figure 4. The maximum calculated displacement was $199 \mathrm{~mm}$ for the design spectrum corresponding to Z4 type soil conditions (soft soil). The deflected shape of the minaret points to mostly lateral flexural deformations, with largest displacement calculated at the roof. The height of minaret roof amounts to 31,25 m, not including the wooden cap. Although the minaret acts as a cantilever structure, the deformation is smaller over the height of a relatively stiff 4,25 m high base. Displacements start to increase above the transition segment at about 5,25 $\mathrm{m}$ in height.

No instructions of direct relevance to assessment/retrofit of slender tower structures made of block stone masonry can be found in Turkish or other seismic codes. Although the Turkish earthquake code is mainly focused on houses and buildings, its basic provisions can nevertheless be used to assess seismic capacity of minaret structures. The calculated roof drift index $(\delta / \mathrm{h})$ amounts to 0,0063 , which is less than the value of 0,01 specified in [10] as maximum roof drift ratio for building structures. In FEMA 273 guidelines, 0,4\% limit drift (bed 
joint sliding behaviour) is proposed for preventing collapse of unreinforced masonry walls (for walls made of hollow or solid bricks, and clay/concrete units) [17].

It can be seen from previous studies investigating causes of post-earthquake failure of minarets that most of masonry minarets usually fail at the bottom part of the cylindrical body, just above the transition zone [7]. For the minaret considered in this study, the maximum stress values determined through FEM analysis amount to $-11,32 \mathrm{MPa}$ (compression), 9,20 MPa (tension) i 0,72 MPa (shear), as shown in Figures 5 and 6. Tensile stresses greatly exceed the tensile strength capacity of the limestone, the maximum capacity of which is estimated at 1,0 MPa [9]. High tensile stresses mainly occur in lower segments of the minaret, which is why its structure is highly susceptible to seismic load. In addition, in terms of roof drift, the design value of 0,0065 (199 mm of roof displacement) is higher when compared to similar types of slender masonry structures. Under these circumstances, it is clear that historic structures of this type are greatly vulnerable to strong seismic action. On the other hand, the seismic resistance

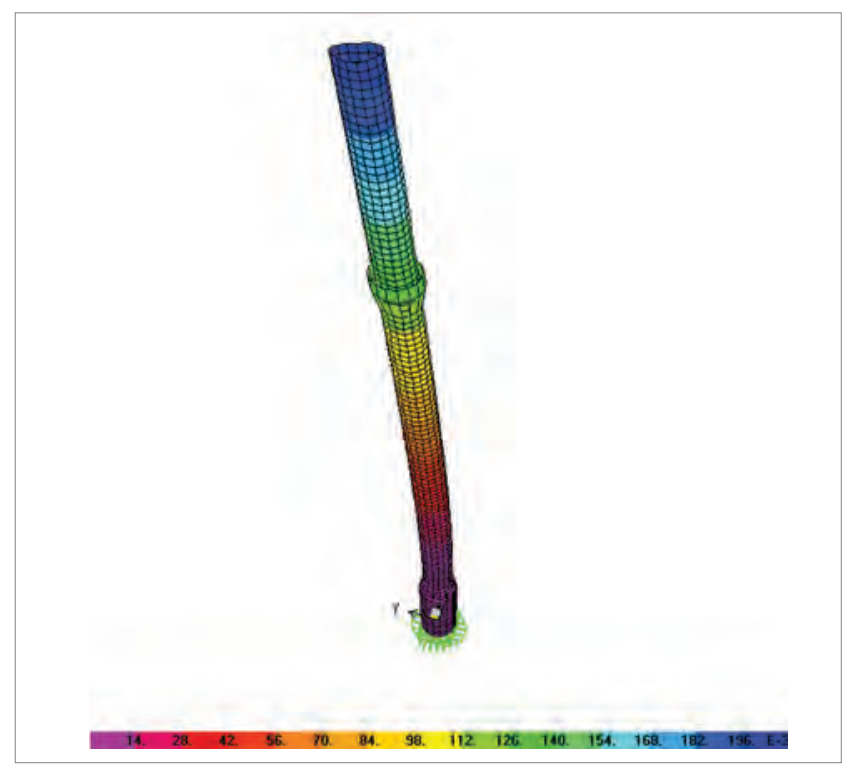

Figure 4. Deflected shape and lateral displacement over the minaret height (in mm) [6]

of such structures additionally decreases because of complex behaviour of stone material, and due to interaction between stone blocks. Furthermore, when conducting any structural intervention of this kind, it is highly significant to preserve initial appearance of the structure.

\section{Structural strengthening with fibre reinforced polymer}

The FRP (fiber reinforced polymer) has been increasingly used over the past decade for seismic strengthening of historical structures. The potential for using FRP jacketing to increase flexural and shear capacity of structures was therefore investigated. As can be seen in Figures 5 and 6, the lower part of minaret - just below and

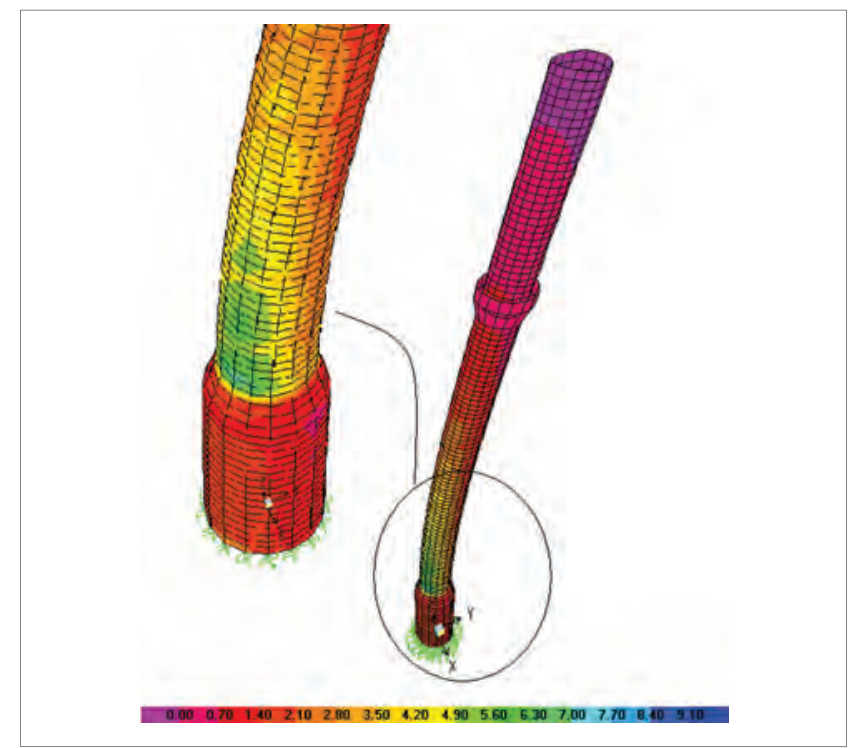

Figure 5. Axial tensile stress distribution over the minaret height (in MPa) [6]

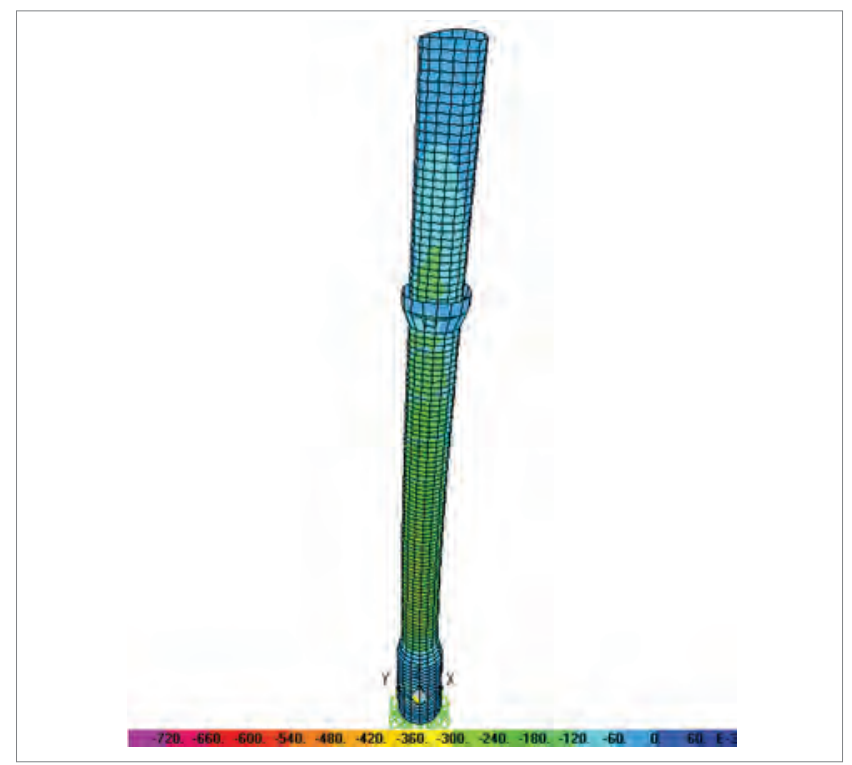

Figure 6. Shear stress distribution along the minaret height (MPa) [6]

above the transition zone - shows weak points in terms of axial and shear stresses. It seems that the use of FRP in these critical zones is an easy and viable strengthening/retrofitting procedure. The full anchorage of FRP material to the stone masonry should be accomplished either by using dowels/anchors while jacketing, or by connecting FRP to foundations of the structure.

According to results obtained during structural upgrading of masonry columns by fibre composites, the following equation may be used to calculate the compressive strength capacity of the lower part of the minaret, when fully wrapped with FRP sheets $[18,19,20]$ :

$$
f_{\text {mod }}=f_{m d}+\frac{g_{m} \cdot 4 \cdot t_{f} \cdot b_{f} \cdot E_{f} \cdot \varepsilon_{l d}}{2000 \cdot D \cdot p_{f}}
$$


The following parameters are used to calculate compressive strength increase for masonry material after the FRP sheets are wrapped around the minaret; $\mathrm{f}_{\mathrm{md}}=12 \mathrm{MPa}, \mathrm{g}_{\mathrm{m}}=2300 \mathrm{~kg} /$ $\mathrm{m}^{3}, \mathrm{E}_{\mathrm{f}}=200000 \mathrm{MPa}, \varepsilon_{\mathrm{fd}}=0.004, \mathrm{t}_{\mathrm{f}}=10 \mathrm{~mm}, \mathrm{~b}_{\mathrm{f}}=500 \mathrm{~mm}$ $\mathrm{D}=3000 \mathrm{~mm}$ i $\mathrm{p}_{\mathrm{f}}=500 \mathrm{~mm}$. The compressive strength of masonry confined in this way may amount to as much as 25 MPa. This capacity is higher than the compressive stresses obtained during analysis, but the tensile strength of the crosssection is still lower when compared to calculated values. The minaret base bending moment resulting from response spectrum analysis amounts to $5200 \mathrm{kNm}$, and the total axial load of the minaret amounts to $1920 \mathrm{kN}$.

Therefore, longitudinal reinforcement in form of FRP strips should be added to FRP jacketing so as to further increase flexural capacity of the cross-section. For this purpose, a cross-section analysis was performed using the XRACT software [21] for cross-section of the lower part of minaret, using the following assumptions: $\mathrm{f}_{\mathrm{m}}=25 \mathrm{MPa}_{\text {, }}$ $\mathrm{E}_{\text {frp }}=200000 \mathrm{MPa}$, maximum assumed tensile strain of FRP in a given cross-section $\varepsilon_{\max }=0,01$, total thickness of FRP strip is $10 \mathrm{~mm}$, and tensile strength of CFRP strips (CFRP - Carbon Fiber Reinforced Polymer) is $2800 \mathrm{MPa}$. After reinforcement, the diameter of the lower part of the minaret was increased to $3020 \mathrm{~mm}$.

The cross-section of the lower part of minaret, wrapped transversally and reinforced longitudinally by FRP, is shown in Figures 7 and 8 . The assumed stress-strain diagram of masonry

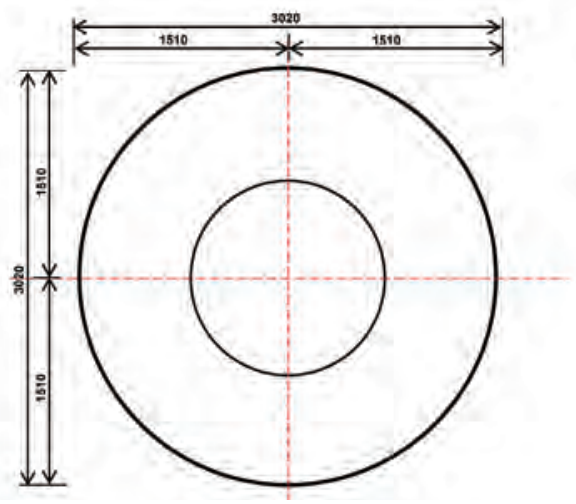

Figure 7. Cross-section of the lower part of minaret wrapped with FRP [6]

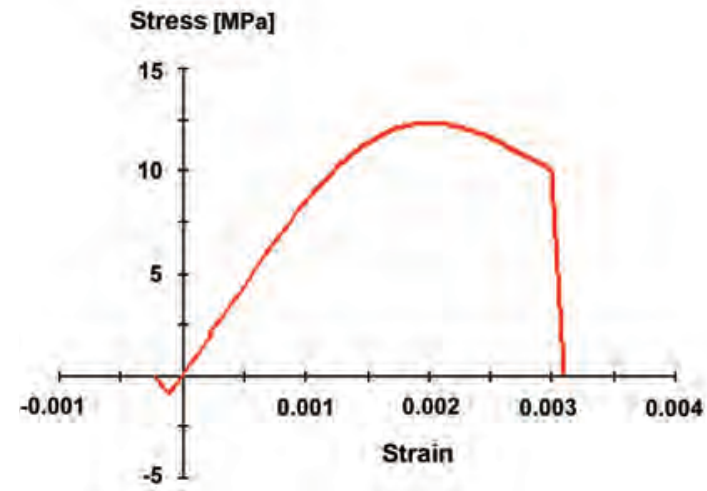

Figure 8. Assumed stress-strain diagram of masonry material [6] material is also shown in these figures. Figure 9 and 10 show the assumed stress-strain diagram of masonry material reinforced by FRP, and the stress-strain diagram for CFRP material [18, 19]. The moment-curvature diagram of the FRP reinforced masonry section is shown in Figure 11, where it can also be seen that the calculated flexural capacity of the minaret complies with requirements.

\section{Conclusions}

This paper presents possible failure modes for a typical historic minaret located in Turkey. The results obtained from ambient vibrations, and previous material tests cited in the paper, show

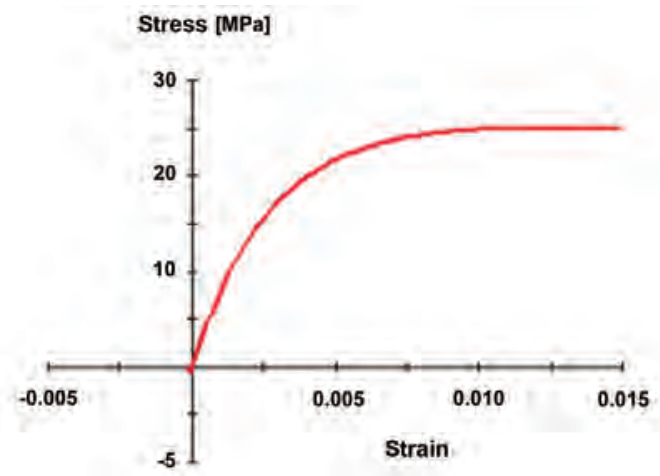

Figure 9. Assumed stress-strain diagram of masonry material reinforced with FRP [6]

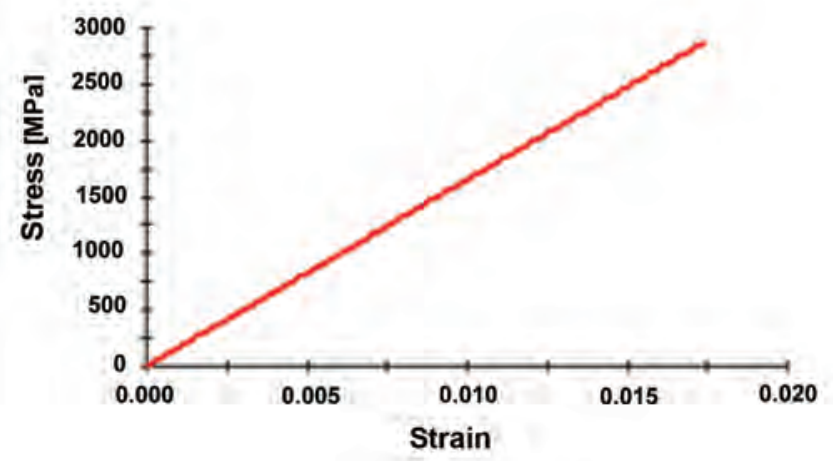

Figure 10. The stress-strain diagram for CFRP material [6]

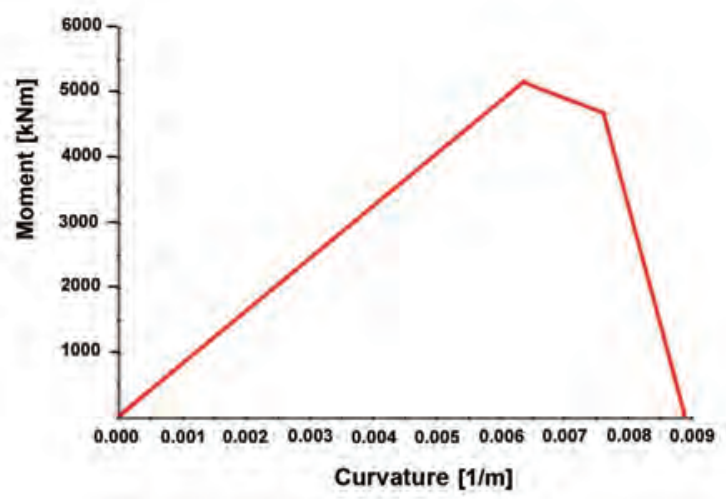

Figure 11. Moment-curvature diagram for reinforced section of the lower part of minaret [6] 
that the behaviour under seismic action can be predicted quite accurately, and that that the mentioned measurements can be used in the assessment of these minarets. The analysis has shown that stability of minarets can be guaranteed in case of a design earthquake ( $10 \%$ probability of incidence in 50 years, strong earthquake) by strengthening those parts of the structure that are most susceptible to damage (base and lower part of the structure).

The 3D analysis presented in the paper enables assessment of structural behaviour of minarets subjected to seismic action, with determination of failure mode, and definition of possible failure zones. Additional investigations should be undertaken to determine those design response spectra that are particularly adapted to this type of structures. More realistic values of $\mathrm{R}$ factor (seismic reduction factor) and damping ratio should be studied both experimentally an analytically. On the other hand, full anchorage between the stone masonry and FRP layers should be ensured. The problem can be solved by using dowels/anchors or by fixing longitudinal FRP strips to minaret foundations. However, attaching FRP to stone masonry may cause moisture problems due to impermeability of FRP layers. Necessary precautions should be taken to ensure proper conservation of historic structures. Low fire resistance of FRP material may be increased by using thin concrete/ mortar cover or coating which would also improve aesthetic appearance of minaret. Results of numerical analysis show that greatest damage usually occurs at the base and lower parts of the minaret, and that lateral behaviour of the structure could be improved by wrapping FRP strips around these critical parts of cross-section. The results obtained may be used for solving problems relating to seismic protection of these and similar historic structures.

\section{Notation}

$f_{c}$ - compressive strength of masonry

$\mathrm{E}$ - modulus of elasticity of masonry material

$\mathrm{f}_{\text {mcd }}$ - the strength of confined masonry

$\mathrm{f}_{\mathrm{md}}$ - characteristic compressive strength of plain masonry

$\mathrm{g}_{\mathrm{m}}$ - specific weight of masonry $\left(\mathrm{kg} / \mathrm{m}^{3}\right)$

$\mathrm{E}_{\mathrm{f}}$ - modulus of elasticity of FRP

$\varepsilon_{\mathrm{fd}}$ - ultimate design strain for FRP

$\mathrm{t}_{\mathrm{f}} \quad$ - thickness of FRP

$\mathrm{b}_{\mathrm{f}}$ - width of FRP strips along the vertical direction fibers are supposed at $90^{\circ}$ with respect to the principal axis of the column

D - diameter of the masonry column

$\mathrm{p}_{\mathrm{f}}$ - distance between two successive FRP strips measured by two axes

\section{REFERENCES}

[1] Oguzmert, M: Yigma Minarelerin Dinamik Davranisi, M.Sc. Thesis, Istanbul Technical University, 2002. (in Turkish)

[2] Cosgun, C.: Silindirik Yigma Yapilarin Lif Takviyeli Polimer ile Takviye Edilmesi, M.Sc.-Thesis, Istanbul Kultur University, 2005. (in Turkish)

[3] Sezen, H., Acar, R., Dogangun, A., Livaoglu R.: Dynamic Analysis and Seismic Performance of Reinforced Concrete Minarets, Engineering Structures, 30, 2008., 2253-2264

[4] Lourenco, P.B.: Recommendations for Restoration of Ancient Buildings and the Survival of a Masonry Chimney, Construction and Building Materials, 20, 2006., 239-251

[5] Lourenco, P.B., Oliveira, D.V., Roca, P., Orduna, A.: Dry Joint Stone Masonry Walls Subjected to In-Plane Combined Loading, Journal of Structural Engineering, 131, 2005., 11

[6] Turk, A. M., Cosgun, C.: The Determination of Seismic Behaviour and Retrofit of Historical Masonry Minaret with FRP, $8^{\text {th }}$ International Masonry Conference, Dresden, 148, 2010., 2029-2038.

[7] Sezen, H., Firat, G.Y., Sozen, M.A.: Investigation of the Performance of Monumental Structures During the 1999 Kocaeli and Duzce Earthquakes, Fifth National Conference on Earthquake Engineering, Istanbul, AE-020, 2003.

[8] Dogangun, A.; Acar, R.; Sezen, H.; Livaoglu, R.: Investigation of Dynamic Response of Masonry Minaret Structures, Bull Earthquake Eng, 5, 2008., 505-517

[9] SAP2000: Integrated Software for Structural Analysis and Design, Computers and Structures Inc., California, 2009.

[10] TSC 2007: Specification for Buildings to Be Built in Disaster Areas, Ministry of Public Works and Settlement, Turkey, 2007.
[11] Arioglu, N., Arioglu, E.: Mimar Sinan'ın Sectigi Tas: Kufeki ve Cekme Dayanımı, 14. Turkiye Insaat Muhendisligi Teknik Kongresi, Izmir, 1997. (in Turkish)

[12] Erguvanli, K., Ahunbay, Z:: Mimar Sinan Istanbul'daki Eserlerinde Kullandigi Taslarin Muhendislik Jeolojisi ve Mimari Ozellikleri, Muhendislik Jeolojisi Bulteni, 11, 1989., 109-114 (in Turkish)

[13] Ahunbay, Z.: Mimar Sinan Yapilarinda Kullanılan Yapım Tekniklerive Malzeme, Mimarbası Kocasinan Yasadıgı Cag ve Eserleri, Istanbul, 1988. (in Turkish)

[14] Arioglu, E., Arioglu, N.: Mimar Sinan'ın Taşıyıcı Olarak Kullandığı Kufeki Tasinin Muhendislik Gizemi, Mimar Sinan Donemi Yapi Etkinlikleri Sempozyumu, Yapı Merkezi, Istanbul, 1999. (in Turkish)

[15] Eurocode 8: Design of Structures for Earthquake Resistance, 1998.

[16] Eurocode 8: Design of Structures for Earthquake Resistance, Part 6 Annex E, 1998.

[17] FEMA 273: NEHRP Guidelines for the Seismic Rehabilitation of Buildings. Federal Emergency Management, Washington, 1997.

[18] CNR 2004: Guide for the Design and Construction of Externally Bonded FRP Systems for strengthening existing structures. Italian Council of National Research, Rome, 2004.

[19] Aiello, M.A., Micelli, F., Valente, L.: Structural Upgrading of Masonry Columns by Using Composite Reinforcements, Journal of Composites for Construction, 11, 2007., 6, 650-658

[20] Galić, J., Sorić, Z., Rak, M.: Strengthening masonry walls subjected to shear load, GRAĐEVINAR 59 (2007) 4, 289-299.

[21] XTRACT V3.0.1.: Cross Sectional Structural Analysis of Components, IMBSEN software systems, 2004. 